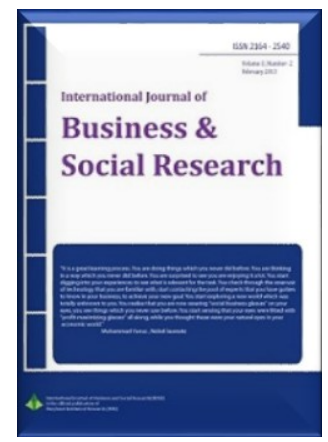

\title{
Leadership and the church: The impact of shifting leadership constructs ${ }^{1}$
}

\author{
Dr. David M. Setley², Dr. Douglas Gautsch³
}

\begin{abstract}
The idea of leadership has been examined for millennia. Examples of leadership in action go back to Moses from the Bible and Xenophón from Greek history. One of the key theories in early leadership is that of charismatic leadership. Although most scholars agree that a key concept of charismatic leadership is that of follower attribution, defining boundaries for charismatic is as difficult as defining leadership itself. This difficulty is accentuated in this work because of the shifting organizational structures and follower perceptions. The case details follower attributed charismatic leadership traits, and then provides a robust discussion on the impact of shifting organizational constructs.
\end{abstract}

Keywords: Charismatic leadership, church leadership, leadership case study, transformational leadership. Available Online: 30-12-2015

This is an open access article under Creative Commons Attribution 4.0 License, 2015.

\section{$1.0 \quad$ INTRODUCTION}

The idea of leadership has been examined for millennia. Examples of leadership in action go back to Moses from the Bible and Xenophón from Greek history. The obstacle in discussing leadership is not in providing examples or generalized concepts but in development of a definition of leadership (Northouse, 2007). There are several well-known scholars who have attempted to encapsulate the concept of leadership in a general definition (e.g. Yukl, 1989), but their effort has not been readily accepted by others (e.g. Bass, 2008; Northouse, 2007).

Perhaps an indicative sign of not only the plethora of attempts to describe leadership but also the plurality of concepts involved in leadership is in the number of leadership theories found in extant literature. Current literature contains no fewer than 65 leadership theories (see Northouse, 2007, p. 2). After a thorough review of the literature, Stogdill (1974, p. 259) suggests that "there are almost as many

\footnotetext{
${ }^{1}$ The authors wish to thank Dr. John Dory, Pace University for his valuable assistance in editing this work.

2 Lebanon Valley College, Department of Business and Economics, Chairperson and Associate Professor of Business Administration, Email: setley@lvc.edu

3 Lebanon Valley College, Department of Business and Economics, Assistant Professor of Business Administration, Email: gautsch@lvc.edu
} 
definitions of leadership as there are persons who have attempted to define the concept." Although earlier attempts to define leadership pointed to traits and physical attributes (e.g. Hollander \& Julian, 1969, Vroom, 1976), more recent attempts to define leadership are typically more centered on behaviors (Kelly, 2008). One leadership theory that has seen a recent resurgence is charismatic leadership.

Work by Dinh et al. (2014) has reviewed a significant number of leadership theories through a metaanalysis of key journal articles (see page 38 of this work for the journal listing). Under their categorization of theories, the Neo-charisma theories category had the highest frequency of articles and the two most referenced theories in this category were transformational and charismatic. Although a number of scholars consider these two theories interchangeable, or at least tangential (e.g. Antonakis, 2012), there are an equal number that disagree (e.g. Bass, 2008). This concept will be discussed further in the literature review.

At this point it is important to discuss the two competing concepts that have evolved in charismatic leadership. Charismatic leadership that involves an exploitative and self-aggrandizing nature is labeled personalized (House \& Howell, 1992; Howell \& Shamir, 2005). Conger (1989) sees this aspect of charismatic leadership in Hitler and Jim Jones. This is not the aspect of charismatic leadership discussed in this work. The second, relevant to this work, is socialized and involves motivation leading to maximum efficiency-typically discussed in relation to organizational behavior. This aspect of charismatic leadership focuses on higher-order goals that appeal to the needs of followers (House \& Howell, 1992; Howell, 1988).

The work by Dinh et al. (2014) attributes charismatic leadership to the work by House (1977), but Weber (1946) is typically credited with the seminal work on charisma and leadership. Antonakis (2012) points to even earlier work found in Aristotle's Rhetoric as the first writings pointing to charismatic traits in leaders. The basis of charisma in each of these works points to the attribution by the respective followers to a leader's charismatic traits. Bass (2008) moves this conversation further by suggesting that charismatic traits can be recognized through individual traits and by the situation, although his discussion of the situational aspect is very limited. Zehndorefer (2014) suggests the situational component is during times of uncertainty, allowing the charismatic leader to provide a vision.

Charismatic leadership theory has moved through several iterations from its initial discussion by Weber (1946), but most scholars continue to view this theory as a follower attributed quality (see the works by Conger) that is somewhat transitory due to the situational component and any movement in the organization's structure. The discussion of organizational structures and the impact of changes in structure to the concept of charismatic leadership is developed in the literature review section of this work. The following case study of the Homily Church of Midtown looks at the aspect of shifts in the follower-leader relationship and at the impact of changes in the organization's structure as it relates to follower attribution of leader qualities. Although much of what is discussed follows Weber's initial work, several incongruities develop that are addressed in our conclusion.

This study continues this work by developing the concept of church leadership using extant literature. During this review it is necessary to compare and contrast charismatic leadership to transformational leadership to address existing confusion within extant literature. The case study that follows presents a recent situation in which charismatic leadership goes through a transformation, providing an excellent platform to discuss its relation to current theory and opportunity to extend current theory. Prior to discussing the specific aspects of leadership relating to transformational and charismatic theories, it is appropriate to discuss the macro aspect of leadership and provide a comparison between leadership in the church and in a for-profit organization.

\subsection{CHURCH LEADERSHIP}

Although according to Stogdill (1974) there are as many leadership theories as there are individuals that have attempted to provide a definition, most leadership theorists would agree that there exists several 
concepts that are central to all leadership theories. Regardless of theory or circumstance, leadership requires followers; this is somewhat axiomatic. One can also suggest that followers conceptualize some level of value or benefit driving the leader / follower relationship.

In a for-profit organization, leadership is primarily seen as the motivating force driving followers toward organizational goal attainment (Northouse, 2013). This type of leadership is typically, although not always, considered assigned leadership (Northouse, 2013, p. 8). One can argue the validity of emergent leadership as well, although this is not as prevalent in organizations where leadership is associated with control (Northouse, 2013). This aspect of control relates to the ability to promote, to increase pay levels, and/or to provide organizational privileges. The aspect of leadership in a church resides within a much different environment.

Many churches today, large and small, are experiencing a continual churn relating to congregates. The term typically used to discuss this is "a back-door problem." This means that members of the congregation will go out the back door, never to return, and this typically is without discussion or notification. Contrary to a for-profit organization, leadership in a church (or for that matter any organization that does not wield some level of control) must be cognizant of follower perceptions and concerns, not in an effort to motivate toward goal completion but to maintain the relationship. This type of leader - follower dynamic requires specific types of leadership skills.

\subsection{CHARISMATIC LEADERSHIP}

Charismatic leadership was originally discussed by Weber (1924) as one of three pillars in his sociological construct of authority and power. Of these three pillars - traditional, rational-legal, and charismaticcharismatic is considered the soft power (Conger \& Kanungo, 1994) because it is determined by follower perception of a leader's skills and not by a leader's rights or position. The traditional concept is rooted in authority based on succession, and rational-legal looks to the profession of management as its foundation (Guillén \& Ibara, 2010). Lorsch (2008) parallels the soft / hard description by labeling traditional and rational-legal as power and charismatic as influence. This may be why House (1977) suggests charismatic leadership is emotional rather than calculative.

Bass's (2008) explanation of the earlier work by Weber (1924) focuses on the mystical and salvation aspect of charismatic leadership. This explanation comes from the perception of charismatic leaders having a personal quality setting them apart from ordinary people. Bass suggests (2008, p 575) that Weber's focus (1947) shifted to the development and maintenance of organizations (see also Dow, 1969 \& Oberg, 1972). This is contrary to the typical interpretation of Weber's 1947 work that suggests charismatic leadership is diametric to organization and organizational structure. Weber (1947) states that charisma cannot be the basis for a stabilized order, such as rational-legal or traditional, without transformation away from charismatic leadership.

A salient point to this discussion is the concept of follower attribution. In Weber's "The theory of social and economic organization" (1947), he is very clear that followers must see the leader as possessing charisma if that leader-follower relationship is to be genuine. In their 1987 work, Conger and Kanungo also attribute charismatic leadership to the followers, as does Willner (1984). This emotional bond exists outside of any rational or established structure, conceptualizing the difficulty in paralleling charisma with either the rational-legal or traditional constructs.

Understanding the aspects of an individual's personality or emotional traits that foundationalize the charismatic attributes is critical to a true understanding of this concept. Because of the ambiguity associated with the concept of charisma, exacerbated by the varying descriptions of charismatic leadership, we cover those traits accepted by the majority of scholars in this field. House (1977) describes these attributes as high levels of self-confidence, dominance, and a strong conviction in moral righteousness (p. 193). 


\subsection{CHARISMA AND ROLE MODELING}

The feature of self-confidence as a characteristic in charismatic leaders can be extended to followers through their development as a result of role-modeling. Role-modeling provides the opportunity for the charismatic leader to establish his or her extraordinary powers (Weber 1947). Role-modeling provides followers an opportunity to visualize their charismatic leader's vision. House (1977) suggests leaders utilize role modeling to establish a value system for followers. Both Weber (1922/1978) and Shils (1965) suggest that the sense of mission and duty that defines charismatic leadership establishes the relationship between leader and follower, which can be established via role modeling.

Antonakis (2012) suggests that this role-modeling concept is used by charismatic leaders as a manner of suggesting power and competence. Bass (2008) states that followers idealize leaders that provide a vision and mission. Antonakis further states that charismatic leaders model behaviors through both imagery and communication. House (1977) expands this aspect of charismatic leadership by advocating that leader self-confidence and conviction are used to model expectations.

Relevant to this discussion is the work by Choi (2006). He suggests alternate descriptors for charismatic leadership traits but his use of envisioning is very tangential to role modeling. Choi describes the concept of envisioning as "the creation and communication of a vision" (p. 27). Choi further suggests that through the envisioning of a new role, the charismatic leader strengthens the bond between leader and follower.

As a central focus of their charismatic leadership model, Conger and Kanungo (2000) discuss the importance of follower perception of their leader's behavioral attributes, often through exemplary acts of the leader witnessed by their followers. They further state that the leader's behavior can significantly influence subordinate reactions, leading to a collective identity and feelings of empowerment.

\subsection{CHARISMATIC LEADERSHIP AND DOMINANCE}

As we mentioned earlier in this work, one of the personal characteristics of charismatic leaders is dominance. Synonyms for dominance are power, authority, and control. House's (1977) use of dominance runs contrary to the discussion by Choi (2006). It is not unusual for diverging descriptions in leadership theory but House captures the concept of dominance as a leader's trait while Choi envisions this as a transference to one's followers. It is this ambiguity that has created the significant variations in charismatic leadership scholarship (see Meindl, 1990).

In House's 1977 work, he links dominance and power with authority and influence, connecting dominance with control of outcomes. Choi (2006) strongly suggests the use of power by a charismatic leader to be the empowerment of followers toward self-efficacy. Choi specifically states that the empowerment of individuals is a "distinguishable behavioral characteristic of a charismatic leader" (p. 28) (see also Bass, 2008, Conger \& Kanungo, 1994). Choi does, however, discuss the attributes of referent and expert power in relation to charismatic leadership. Choi links expert power to the discussion of envisioning and the total concept of empathy, envisioning and empowerment to referent power. If, as part of socialized charismatic leadership, followers visualize the charismatic leader with "extra-ordinary" traits, incorporating expert and referent power into the discussion is certainly axiomatic. It is not apparent to these authors if this is the aspect of innate power House was referring to, but both expert and referent power can be attributed to the leader, albeit as perceived by the follower.

\subsection{CHARISMA, CONVICTION, AND MORAL RIGHTEOUSNESS}

Although in his 1977 treatise House attributes strong conviction and moral righteousness as a key characteristic of charismatic leadership, he does little to develop the discussion. Choi (2006) also does little to discuss the concept of moral righteousness as he foundationalizes charismatic leadership using 
envisioning, empathy, and empowerment and does not associate any of these with moral righteousness. Looking at the work of Weber $(1922,1946,1947)$ as the groundwork for charismatic leadership, scholars use terms such as sacred qualities (Shils 1965), moral vision (Conger \& Kanungo, 1987), moral justification (Bass, 2008), and moral commitment (Shamir, House, \& Arthur, 1993) to describe attributes.

Certainly the original works by Weber $(1922,1946,1947)$, which used terms like protestant ethics, focused on conviction and moral righteousness. Although more current literature does not share the same words, the salient meaning of reverence and morality as a justification for charismatic leadership still exists (Conger, Kanungo, \& Menon, 2000). An obvious point for clarification is what has changed in the academic understanding of charismatic leadership from the time of Weber until now.

\subsection{NEO-CHARISMATIC THEORY}

When Weber began the discussion on charismatic leadership, he positioned the concept as ephemeral. The structural aspect of an organization (i.e. the rational or traditional) negated the key characteristics that underpin this concept $(1922,1946,1947)$. Beginning with House and continuing with Arthur, Conger, Kanungo, Menon, Shamir and others, charismatic leadership emerged as a viable leadership theory in organizations. Beyer (1999) suggests that this academic search for an inclusive definition for charismatic leadership is tangential to the search for a theory demarking leadership from non-leadership, one that continues today (see Northouse for a discussion on scholarly attempts to define leadership). This research posits that the defining difference between Weber's earlier position and the neo-charismatic structure is accepting charisma as a leadership pillar in rational organizational structures. Weber's position was diametric to any position in a rational-legal structure, but today's scholars suggest it does have a place, and in fact is a key motivational force in follower performance. Bass (2008) goes as far as to suggest that charismatic leadership unleashes productivity within an organization at a much greater level than other types of leadership. (p. 449) (see also Howell, 1985). Although there is current work that continues to follow the original work of Weber (e.g. Smith, 2000), the majority of current scholarship suggests that charismatic leadership is a viable paradigm in organizational behavior studies.

\subsection{CHARISMATIC AND / OR TRANSFORMATIONAL LEADERSHIP}

Before proceeding with the case study, it is of value to briefly enter the discussion of the relationship between charismatic and transformational leadership. A number of academics consider these two leadership concepts as interchangeable or at the very least tangential (e.g. Burns, 1978), while others (Yukl, 1989) see little or no comparison. Bass (2008) suggests that charisma is but one essence of transformational leadership.

The value of entering this discussion is to further highlight the lack of specificity in charismatic leadership and the need for additional research. The following case study provides a real-life example of charismatic leadership, follows the leader through a maturation of both followers and organization, and points to specific changes that impact the relationship between leader and follower.

\subsection{METHODS APPROACH}

Studying human behavior using only quantitative methodologies is being questioned more and more as somewhat myopic (Alvesson, 1996). It is increasingly the opinion of others (e.g. Alvesson, 1996; Yukl, 1989) that measuring behaviors through quantitative methods can only produce a measurement of the outcomes of leadership behaviors but not the specific, actual behaviors. At the very minimum, a mixed methods approach should be utilized (Stentz, Plano, \& Matkin, 2012).

A qualitative or mixed methods review of leadership activities based on an actual experience(s) can provide not only an accurate picture of leadership but can also allow for a much richer understanding of the nuances of the process. Following the work of Northouse (2007) and Rowe (2007), a case study 
relating to leadership can provide a more inclusive perspective of leadership and the charismatic leadership theory in particular. Stake (1978) writes that when the purpose of research is to expand understanding through the extension of experiences and to enhance conviction, the case study method is useful. Stake adds that, because the nature of the case may be tangential to the reader's experiences, it may become generalizable to that individual. This concept suggested by Stake is predicated on the opportunity for readers to relate their own tacit knowledge to the experience being depicted.

\subsection{THE CASE OF THE HOMILY CHURCH}

The Homily Church of Midtown (name disguised) thrived for over two decades with its growth earning national recognition. Proclaimed the model of the new mega-church for the $21^{\text {st }}$ century, the congregation peaked at over 3,000. Then, decline replaced growth as long-term congregates left, new membership waned, and dissention began. Leadership appeared to play a substantial role throughout the church history.

\subsection{THE EARLY CHURCH}

In 1970 the Homily Church originated as a bible study group of various individuals meeting in the home of a founder. Within six months, the group recruited young Rev. Brian Carter (name disguised) as their pastor. Two years later, growth drove the group to begin holding services in a local fire hall and a few months later it moved to the municipal community center. In 1976 the congregation completed construction of its own church building. One year later, continued growth required the church to hold two services on Sunday mornings.

Throughout its first decade, the church expanded its functions from Sunday worship and small group bible study to include Sunday school, community services, and missionary sponsorship. To support these activities, the church purchased and reconfigured surrounding buildings. In 1986 the church began construction of a larger worship area. When it celebrated its twenty-fifth anniversary, the denomination's governing body declared the Homily Church an official mega-church. The growth plateaued at 3,000 congregates in 1995.

To support growth of congregates and breadth of activities, the church organization also developed. Rev. Carter became the Senior Pastor and continued to officiate at worship services. The church continually recruited full-time Associate Pastors to manage its expanding range of ministries and activities. Also, the number of elders increased from three to twenty-four by 1995 . Collectively, the elders acted as a board of trustees for the Homily Church. In the tradition of Timothy and Titus (Pauline epistles found in the New Testament), the congregation elected as elders adult males who were exemplars of the Christian faith and above reproach. Elders could not serve more than two consecutive three-year terms. By 1995, the church had 11 pastors and 24 elders.

To supplement and support the full-time paid ministers of the church, many congregates volunteered or were recruited to be members of committees to carry out the ministries of the church. Over time, some visible members assumed increasing responsibility, became committee chairs, and later often were elected as Elders. As the church grew in size and complexity, the committee structure became more formal and hierarchical. Nevertheless, participants described their relationships with one another and the ministers as one of mutual respect and concern.

Throughout this period, the congregation highly regarded Rev. Carter as a wise spiritual counselor, a strong moral teacher, a learned biblical scholar, and an engaging inspirational speaker. His teachings resonated deeply with the congregation. As a sign of respect and affection, members of the congregation often referred to Homily as "Reverend Carter's Church" or "Brian's Church." As an administrator, he encouraged broad participation by the associate pastors, elders, and interested 
members of the congregation in the decisions of the church, especially those related to its growth and development. He was viewed as apolitical and transparent.

Until 1995, the board of elders met monthly in closed session and conducted open administrative meetings for the congregation semiannually. At the open meetings the pastor and the elders discussed with the congregation the opportunities and problems facing the church; proposed and explained future plans; and asked the congregation to vote their approval or disapproval. The plans related to many issues, including physical expansion, fund raising, new activities, and personnel appointments.

\subsection{THE TRANSITION}

In 1995, the board proposed and the congregation approved a change in the bylaws that ceded all formal and legal decisions to the board, except the selection of the Senior Pastor. Although the semiannual administrative meetings continued for a while, they were cancelled on occasion due to insufficient attendance. During these meetings the elders did not solicit opinions from the congregation and did not ask for votes. At one meeting a congregate asked if the elders were seeking input from the congregation, and the Head Elder replied, "I have already made my decision, I am simply telling you what it is."

Following the bylaw change, two trends developed. First, attendance at the semiannual administrative meetings declined precipitously. Second, the size of the congregation began to decrease. Both of these trends appeared to result from not only a diminished inflow of new congregates but also from a significant outflow of existing congregates, especially among those who had been members of the church for the longest period of time.

Members who joined the congregation in the 1970s became disenchanted with the change in governance and the closed decision process. In addition to feeling disenfranchised from decisions, they claimed decisions were either ill-conceived or poorly communicated. Several "founding families" withdrew support, severed ties, and joined other churches of the same denomination. Others became disgruntled but remained, only to be seen as negative members becoming more peripheral in the life of the church. Between 1997 and 2007, the congregation declined 43\% from over 3,000 members to about 1,700. During that same period, weekly collections also declined by about $35 \%$. The church responded to these declines by reducing the number of associate pastors and some other paid staff. The reduction in staff and services lead to more dissatisfaction within the congregation.

After a decade of decline, Rev. Carter acknowledged the need for change and announced his retirement. The congregation had not expected this because the Senior Pastor had not reached the age requirement for retirement funds. His announcement hastened the exit of additional congregates who had been his strongest supporters and devotees.

\subsection{THE RENEWAL}

The new Senior Pastor was hired in 2009. Over the next two years he realigned the staff through both downsizing and replacing several of the then current pastors. The transition and realignment of the Homily Church staff proved to be significant in several areas. The pastoral staff was reduced from its preshift numbers by $10 \%$ and the Elder Board was ultimately reduced by $42 \%$. There were administrative personnel changes but those changes were less significant to the congregation.

From 2009 to 2011 the change process was continual. This ongoing change, along with the retirement of the long-time previous Senior Pastor, initially continued the congregate exodus. The change process under the new Senior Pastor culminated in a more egalitarian staff than was previously in place. A key difference between the circa 1995 church leadership and the 2011 was the interface between the congregation and the Senior Pastor. Although the new Senior Pastor is more scholarly than his predecessor, he is much less interactive with the individual congregates. The more introverted nature 
forced the church leadership to hire an executive pastor - a new position - as the leadership interface between the congregation and the staff.

The new Senior Pastor is not charismatic in nature, but the new team of pastors and elders, as an entity, are transformational. Over the next two years the congregation grew by 550 members. Congregate attendance at the semi-annual meeting grew and, although the budget was again reduced, giving per person increased from its previous low.

\subsection{CASE ANALYSIS}

One advantage of studying leadership in religious organizations is that the shared beliefs and values of clergy and laity remain consistent and strong over extensive time periods. Studies of leadership often include beliefs and values as a variable that requires discovery through social processes (e.g. Dulebohn et al., 2011) and may also evolve over time (Graen \& Uhl-Bien, 1995). Religions espouse belief systems about the meaning and origin of life usually explained in terms supernatural beings and a spiritual existence that transcends human life and spans human experience. They also instill value systems that ascribe how members should relate to these supernatural beings and to other natural beings-i.e., how to live a natural life acceptable to the supernatural beings and prepare for a spiritual life after death. Especially in Christian denominations (e.g., Baptist, Catholic, Episcopal, Lutheran, Methodist, and Presbyterian) these systems are well defined, widely shared and powerfully institutionalized. They provide a social organization that helps their members to better understand these systems of beliefs and values and to behave in ways consistent with these systems.

A second advantage of studying leadership in religious organizations is that many members can easily leave one church and join another because more populated areas have multiple churches of most denominations. The motivations that bind people to a specific church and motivate their affiliation and participation are primarily psychological and sociological in nature. One strong motivation is an individual's perception about the leader (pastor).

By comparison, studies of leadership in commercially-based organizations must also consider employee motivations related to physical variables such as economic dependency and employment mobility. (In many churches, the pastor is economically dependent on the followers.) Although some people build their family and social environment within church congregations, many others view a congregation as one of many organizational affiliations-they can move from one congregation to another without disrupting their other social relationships.

The founding of the Homily Church and the early selection of Rev. Carter as its pastor was initially based primarily on shared beliefs and values anchored in studying the bible. The founding families were strongly committed to them and followed Rev. Carter because he not only shared them, but also reinforced the beliefs and inspired behavior that reflected the values.

Over time, the early followers were attracted to many of the personal characteristics of Rev. Carter. From a theoretical viewpoint, they came to view him as a charismatic leader. Since he practiced what he preached, he became their role model for Christian behavior. His inspirational sermons from the pulpit, cogent explanations during committee meetings, and persuasive counsel in more personal settings enabled him to dominate situations, control outcomes, create visions, and empower individuals. Because of his education and training, he could defend his strong religious convictions and convince followers of moral righteousness.

Part of the accepted vision empowered followers with a missionary zeal to recruit new members. As the Homily Church grew, it required a hierarchy to support its expanding ministries and activities. Being among Rev. Carter's most avid followers, the earlier members of the congregation often created, sought, or accepted positions within the hierarchy responsibility for fulfilling their mutual vision. Reflecting their exemplary behavior, many were also elected to serve as Elders of the church. By 1997, most of the 
founders had served their maximum terms as elders and newer members of the congregation replaced them in this role.

As the growth continued, some newer members emulated the founders. However, others were less committed to the church and less willing to contribute their time to assume positions in the hierarchy. When the Elders asked the congregation to give them authority to make all the major decisions for the church, many of the later mentioned newer members voted yes to limit their own future involvement in those decisions. Others, including the founding families and earlier members, felt more isolated from the affairs of the church and from the pastor. As a result of the vote, the Elders felt relieved that they no longer needed to "sell" their plans to the congregation.

However, with the increasing church membership and positions in the hierarchy, Rev. Carter found himself devoting more time to administering the hierarchy and less time ministering directly to individual and small group needs and wants. He relied increasingly on worship services and large group meetings to maintain his leadership position. This reduced interaction with the founding members strained the relationships between him and them. In turn, they felt increasingly disillusioned and disenfranchised. Some became disenchanted and withdrew from active participation in the church. Some others left in search of a new leader in another congregation that could fulfill their expectations.

From a theoretical viewpoint, many members perceived Rev. Carter's charisma to be considerably reduced. While, they all continued to share the same beliefs and values, the situation had changed. The size and complexity of the church distracted the leader and his followers from the original vision of becoming "better people." This complexity and distraction included multiple ministries, many elders and associate pastors, maintaining the hierarchy, operating larger physical facilities, and preoccupation with finances, budgets, and scheduling. The declining membership and contributions exacerbated the situation. By 2007, Rev. Carter realized that his leadership lacked charisma and the Homily Church lacked the resources to function properly under his leadership.

\subsection{CONCLUSION}

An intuitive analysis of a "house of faith" would focus on the aspect of values that foundationalize the bond between the individual congregates and the leader(s) of that organization. Analytical discussions on this topic typically visualize as key to this bond the relationships that exist, both horizontally-other congregates-and vertically — church leadership. As we have discussed in this work, the impact of the members' discernment of their relationship with the church leader(s) can have a significant impact on individual member affective commitment to that institution.

The church discussed in this case originally coalesced around the common values that substantiated their faith. The new senior pastor of this nascent organization espoused those same values. The maturation of those values and the unprecedented growth of this church substantiated the vision of this senior pastor as a charismatic leader. Previously defined in this work, the rationalization of a charismatic leader is engendered by the followers' perception of a phenomenal trait of the leader. In this study the phenomenal trait perceived by followers was the leader's ability to grow the church at an exponential rate. This ability was rationalized by the followers as the senior pastor's concern for his flock. There was also the development of a level of trust based on the leader's distinguished traits and perceived value congruence. However this turned out to be a false construct.

As the church shifted its structure from a predominantly horizontal platform to a much more vertical one, the perception of the followers began to wane. This work has built the concept of charismatic leadership solely on followers attributing one or more traits to the leader that the followers see as exceptional. As the church structure made its pronounced shift, it became evident that many of the followers reevaluated the basis of their trust in the senior pastor and began to question the value congruence. As discussed in this case, the charismatic structure is considered by many scholars a transitory phenomenon, leading to traditional or rational-legal structures. It is very important to note that these same congregates 
did not question those values which foundationalized their belief. Those members that eventually left the church, many of which were founding members, immediately joined other churches expressing those same originating values.

It is quite obvious that the values of these congregates did not change. The senior pastor's day to day activities did not appear to change in a punctuated manner. The element that did shift was the underlying structure of the organization. The basic shift in the organization came with the elements of control and trust. When the ability to provide input into the decision-making process was taken away from the congregation, trust between the congregation and the pastoral staff became strained.

Charismatic leadership is based solely on the evaluation of the follower on a leader's traits, not on any absolutes or skills the leader actually has. Although charismatic leadership is leader-centric, followers in this study perceived a strong relationship between themselves and their senior pastor pre-1995. Regardless of whether or not there was a change in the leader's traits, skills, or attitude, the congregation envisioned a gap between themselves and the leader when the structure changed and the perceived charisma of this leader was gone for these followers.

\section{REFERENCES}

Alvesson, M. (1996). Leadership studies: From procedure and abstraction to reflexivity and situation. Leadership Quarterly, 7(4), 455-485.

Antonakis, J. (2012). Transformational and charismatic leadership. In David Day \& J. Antonakis (Eds.), The Nature of Leadership (2nd ed.) (pp. 256-288). Thousand Oaks, CA: Sage

Bass, B. M. (2008). The Bass handbook of leadership: Theory, research, and managerial applications. (4th ed.). New York: Free Press

Beyer, J. M. (1999A). Two approaches to studying charismatic leadership: competing or complementary? Leadership Quarterly, 10(4), 575-588.

Burns, J. M. (1978). Leadership. New York: Harper \& Row.

Choi, J. (2006). A motivational theory of charismatic leadership: Envisioning, empathy, and empowerment. Journal of Leadership \& Organizational Studies, 13(1), 24-43.

Conger, J. A. (1989). The Charismatic Leader. San Francisco: Jossey-Bass.

Conger, J. A. \& Kanungo, R. N. (1987). Toward a behavioral theory of charismatic leadership in organizational setting. Academy of Management Review, 12(4), 637-647.

(1994). Charismatic leadership in organizations: Perceived behavioral attributes and their measurement. Journal of Organizational Behavior, 15(5), 439-452.

Conger, J. A., Kanungo, R. N., \& Menon, S. T. (2000). Charismatic leadership and follower effects. Journal of Organizational Behavior, 21, 747-767.

Dinh, J. E., Lord, R. G., Gardner, W. L., Meuser, J. D., Liden, R. C., \& Hu, J. (2014). Leadership theory and research in the new millennium: Current theoretical trends and changing perspectives. Leadership Quarterly, 25(1), 36-62.

Dow, T. E., (1969). The theory of charisma. Sociological Quarterly, 10, 306-318.

Dulebohn, J. H., Bommer, W. H., Liden, R. C., Brouer, R. L., \& Ferris, G. R. (2012). A meta-analysis of Antecedents and Consequences of leader-member exchange: Integrating the past with an eye toward the future. Journal of Management, 38, 1715-1759.

Graen, G. B., \& Uhl-Bien, M. (1995). Relationship-based approach to leadership: Development of leadermember exchange (LMX) theory of leadership over 25 years: Applying a multi-level multi-domain perspective. Leadership Quarterly, 6(2), 29-247.

Guillén, L., \& Ibara, H. (2010). Seasons of a leader's development: Beyond a one-size fits all approach to designing interventions. Retrieved from http://www.insead.edu/ facultyresearch/research/doc.cfm?did=43958 on October 10, 2014.

Hollander, E. P., \& Julian, J. W. (1969). Contemporary trends in the analysis of leadership processes. Psychological Bulletin, 71(5), 387-397. 
House, R. J. (1977). A 1976 theory of charismatic leadership. In J. G. Hunt \& L.L. Larson (Eds.), Leadership: The cutting edge (pp. 189-207). Carbondale, II: Southern Illinois University.

House, R. J., \& Howell, J. M. (1992). Personality and charismatic leadership. Leadership Quarterly, 3, 81108.

Howell, J. M. (1985). A laboratory study of charismatic leadership? (Working Paper No. 85-35). London, ON: School of Business Administration, University of Western Ontario.

---- (1988). Two faces of charisma: Socialized and personalized leadership in organizations. In J. A. Conger \& R. N. Kanungo (Eds.), Charismatic leadership: The elusive factor in organizational effectiveness (pp. 213-236). San Francisco: Jossey-Bass.

Howell, J. M., \& Shamir, B. (2005). The role of followers in charismatic leadership process: Relationships and their consequences. Academy of Management Review, 30, 96-112.

Kelly, S. (2008). Leadership: A categorical mistake? Human Relations, 61(6), 763-782.

Lorsch, J. (2008). A contingency theory of leadership. Retrieved from peoplelearn.homestead.com/contingency2.pdf on November 12, 2014.

Meindl, J. R. (1990). On leadership: An alternative to the conventional wisdom. In B. M. Staw \& L.L. Cummings (Eds.), Research in Organizational Behavior (Vol. 12, pp. 159-203). Greenwich, CT: JAI Press.

Northouse, P. G. (2007). Leadership: Theory and practice (4th ed.). Thousand Oaks: Sage

- (2013). Leadership: Theory and practice (6th ed.). Thousand Oaks: Sage

Oberg, W. (1972). Making performance appraisal relevant. Harvard Business Review, 50(1), 61-67.

Rachman, A. W. (2003). Issues of power, control, and status in group interaction: From Ferenczi to Foucault. Group, 27(2/3), 89-105.

Rowe, W. G. (2007). Cases in Leadership. Thousand Oaks, CA: Sage.

Shamir, B., House, R. J., \& Arthur, M. B. (1993). The motivational effects of charismatic leadership: A selfconcept based theory. Organization Science, 4(4), 577-594.

Shamir, B., \& Eilam, G. (2005). "What's your story?" A life-stories approach to authentic leadership development. Leadership Quarterly, 16(3), 395-417.

Shils, E. (1965). Charisma, order, and status. American Sociological Review, 30, 99-213.

Smith, P. (2000). Culture and charisma: outline of a theory. Acta Sociologica, 43(2), 101-111.

Stake, J. E. (1978). Motives for occupational goal setting among male and female college students. Journal of Applied Psychology, 63(5), 617-622.

Stentz, J. E., Plano, C., \& Matkin, G. S. (2012). Applying mixed methods to leadership research: A review of current practices. Leadership Quarterly, 23(6), 1173-1183.

Stogdill, R. M. (1974). Handbook of leadership: A survey of the literature. New York: Free Press.

Vroom, V. H. (1976). Leadership. In M. D. Dunnette (Ed.), Handbook of Industrial and Organizational Psychology (pp. 1527-1551). Chicago: Rand McNally.

Weber, M. (1922/1978). Economy and society. (G. Roth \& C. Wittich, Eds.). Oakland, CA: University of California Press.

----- (1946). Essays in Sociology (Hans Gerth \& C. W. Mills, Eds. and Trans.). New York: Oxford University Press.

(1947). The theory of social and economic organizations (A. M. Henderson \& T. Parsons, Eds. And Trans.). Glencoe, IL: Free Press.

Willner, A. R. (1984). The Spellbinders. New Haven: Yale University Press.

Yukl, G. (1989). Managerial leadership: A review of theory and research. Journal of Management, 15(2), 251-289.

Zehndorefer, E. (2014). Leadership: A critical introduction. NYC, NY: Rutledge. 